\title{
Horsehair Worms, Hairworms, Gordian Worms, Nematomorphs, Gordius spp. (Nematomorpha: Gordioidea) ${ }^{1}$
}

J. L. Capinera ${ }^{2}$

\section{Distribution}

This relatively small group of large worms is found throughout world, but usually is restricted to areas near water. About 11 species occur in the United States. They are commonly confused with mermithid nematodes. Poinar (1991) provides a key to genera found in North America. Baker and Capinera (1997) provide a summary with emphasis on nematomorphs affecting grasshoppers.

\section{Description and Life Cycle}

The adults are free-living but the juveniles are parasitic. The preparasitic worms are minute, and infect their host when they are accidentally ingested. They cannot penetrate hosts from the outside. Nematomorphs infect insects, including crickets, cockroaches, beetles, mantids, and grasshoppers, but also spiders and woodlice (sowbugs).

The species most commonly encountered, and perhaps the best studied species, is Gordius robustus.
It occasionally attains high densities in its tettigoniid host Anabrus simplex Haldeman, also known as the Mormon cricket. The following information is based on G. robustus.

\section{Egg}

The minute, ovate eggs are only about 40 microns wide and 50 microns long. They are deposited in water, in slender strips held together with gelatinous material. The number of eggs produced per female is enormous; Thorne (1940) estimated 27 million eggs form a single female. The eggs are deposited in the spring after the adults move from their overwintering sites in soil, under rocks, and in organic debris. Shallow water, including swamps, pools and streams, are acceptable oviposition sites.

\section{Larvae}

Apparently larvae swim about freely in the water after hatching, and are ingested with water when insects drink. Once inside a host insect, the larva

1. This document is EENY-117, one of a series of Featured Creatures from the Entomology and Nematology Department, Florida Cooperative Extension Service, Institute of Food and Agricultural Sciences, University of Florida. Published: October 1999. Revised: December 2004. This document is also available on Featured Creatures Website at http://creatures.ifas.ufl.edu. Please visit the EDIS Website at http://edis.ifas.ufl.edu. Additional information on these organisms, including many color photographs, is available at the Entomology and Nematology Department website at http://entnemdept.ifas.ufl.edu/.

2. J. L. Capinera, professor/chairman, Entomology and Nematology Department, Cooperative Extension Service, Institute of Food and Agricultural Sciences, University of Florida, Gainesville, FL 32611.

The Institute of Food and Agricultural Sciences (IFAS) is an Equal Employment Opportunity - Affirmative Action Employer authorized to provide research, educational information and other services only to individuals and institutions that function without regard to race, creed, color, religion, age, disability, sex, sexual orientation, marital status, national origin, political opinions or affiliations. For information on obtaining other extension publications, contact your county Cooperative Extension Service office. Florida Cooperative Extension Service / Institute of Food and Agricultural Sciences / University of Florida / Larry R. Arrington, Interim Dean 
penetrate the insect's gut and enter its body cavity. They mature and escape from the host in two to three months. Thorne (1940) suggests that emergence from the adult occurs only in the presence of water, though the mechanism for detection of water is unknown. Thomas et al. (2002) showed that infected hosts are more likely to enter water than non-infected hosts.

\section{Adults}

These worms resemble nematodes, but are very long, usually 30 to $40 \mathrm{~cm}$ but sometimes $120 \mathrm{~cm}$ in length, and quite narrow in diameter, often only 1 $\mathrm{mm}$. The adults are featureless, with a blunt head and slightly swollen tail. The color is usually mauve-brown to black. The sexes are separate.

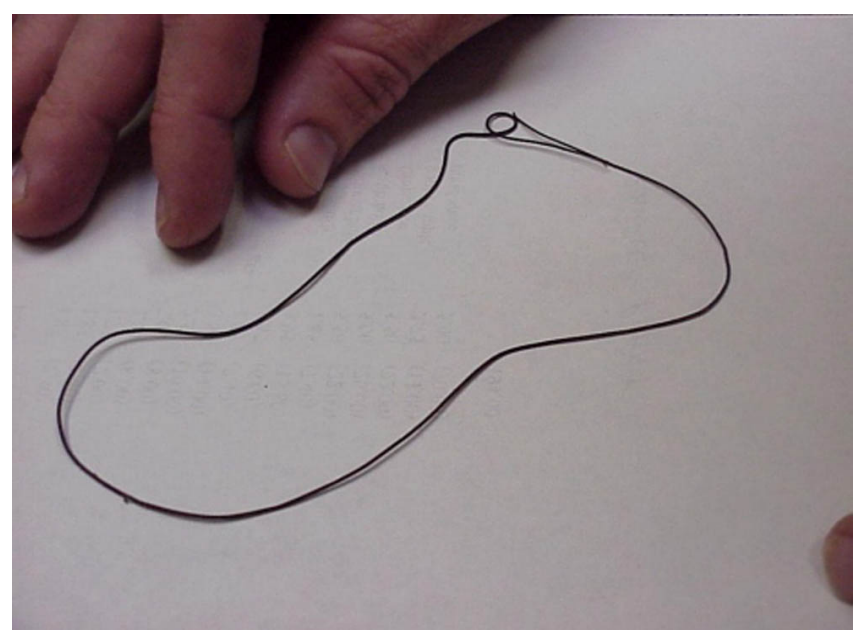

Figure 1. Adult of horsehair worm (nematomorph). Credits: Sharon LaPlante

\section{Importance}

The impact of horsehair worms is highly variable, but usually slight. Because insects must drink from free water in order to be infected, few seem to acquire these parasites. Also, they must be long-lived in order for the worms to complete their development. However, Thorne (1940) reported an infection level of $99 \%$ at one site, so the potential effect is great. Insects infected by nematomorphs rarely produce eggs. Even a single worm is large relative to hosts, so sexual development is eliminated. Horsehair worms are mostly a curiosity and come to people's attention because of their large size and sinister appearance. Their common name, horsehair worm, is derived both from their long thin appearance and the fact that they sometimes occur in livestock watering tanks, where they emerge from drowned grasshoppers that carelessly landed upon water.

\section{Selected References}

Baker, GL and JL Capinera. 1997. Nematodes and nematomorphs as control agents of grasshoppers and locusts. Memoirs of the Entomological Society of Canada. 171: 157-211.

Poinar, GO, Jr. 1991. Nematoda and Nematomorpha Pages 249-283. In Thorp, JH and AP Covich (eds.) Ecology and Classification of North American Freshwater Invertebrates. Academic Press, San Diego, CA.

Thomas F, Schmidt-Rhaesa A, Martin G, Manu C, Durand P, Renaud F. 2002. Do hairworms (Nematomorpha) manipulate the water seeking behavior of their terrestrial hosts? Journal of Evolutionary Biology 356-361.

Thorne, G. 1940. The hairworm, Gordius robustus Leidy, as a parasite of the Mormon cricket, Anabrus simplex Haldeman. Journal of the Washington Academy of Science 30: 219-231. 